\title{
ONE-POT SYNTHESIS AND ANTIMICROBIAL SCREENING OF NEW [1,5] -BENZODIAZEPINE DERIVATIVES CATALYZED BY TBAB
}

\author{
Kamal M. El-Gaml
}

Organic Chemistry Department, Al-Azher University, Nasr City , Cairo,11884, Egypt

\begin{abstract}
:
A new [1,5]-benzodiazepines (VI) were synthesized by the reaction of $o$ phenylenediamine with 2-chloro-3-acetylquinoline in the presence of tetrabutyl ammonium bromide (TBAB) in short reaction time with excellent yield.
\end{abstract}

Keywords: tetrabutyl ammonium bromide ,[1,5]- Benzodiazepine,2-chloro-3acetylquinoline derivatives, $o$-phenelendiamine .

\section{INTRODUCTION}

Benzodiazepines are one of the most important class that have various therapeutic applications. Many members of the benzodiazepine family have a wide range of biological activity as anticonvulsants, anti-anxiety, analgesic, sedative, anti-depressant, hypnotic (Randall, 1974) anti-inflammatory (Roma, et al., 1991), anti-viral (Kavali and Badami, 2000), anti-HIV (Di Braccio, et al., 2001), antimicrobial, (Kumar and Joshi, 2007) and anti-tumor (Kamala, et al., 2008) ctivities. Accordingly 1, 5-Benzodiazepine and its derivatives attract our attention to synthesize new members depending on wide range of pharmacological activity and industrial applications, the development of mild and efficient protocols for their preparation continues to be a challenging endeavor in the synthetic organic chemistry (Herbert, et al., 1974). The common procedure for the synthesis of these compounds is a one pot condensation between $o$-phenelendiamine and newly synthesized carbonyl compounds . However, from the modified literature survey a variety of catalysts such as $\mathrm{BF}_{3} \mathrm{O}, \mathrm{NaBH}_{4}, \mathrm{PPA}-\mathrm{SiO}_{2}, \mathrm{MgO}-\mathrm{POCl}_{3}, \mathrm{Yb}(\mathrm{OTf})_{3}$, amberlyst-15, $\mathrm{Ag}_{3} \mathrm{PW} 12 \mathrm{O} 40$, solid super acid sulphated zirconia, acetic acid - under MWI, AgNO3, zinc montmorilonite as catalyst at room temperature were used. These reactions also occur with various catalysts under solvent free conditions (Chen and Lu, 2005; Kumar, et al., 2006; Li, et al., 2007; An, et al., 2008; Mohamed and Asgar, 2012; Heravi, et al., 1985). Indeed these methodologies have several disadvantages such as harsh reaction condition, long reaction time, a large amount of catalysts, expensive reagents, unsatisfactory product yields, critical product isolation procedures, tedious workup and formation of side products. Keeping in mind in the present study we have developed one pot synthesis of [1,5]-benzodiazepines by condensation of $o$-phenelendiamine with ketones catalyzed by tetrabutylammonium bromide (Scheme 1). 


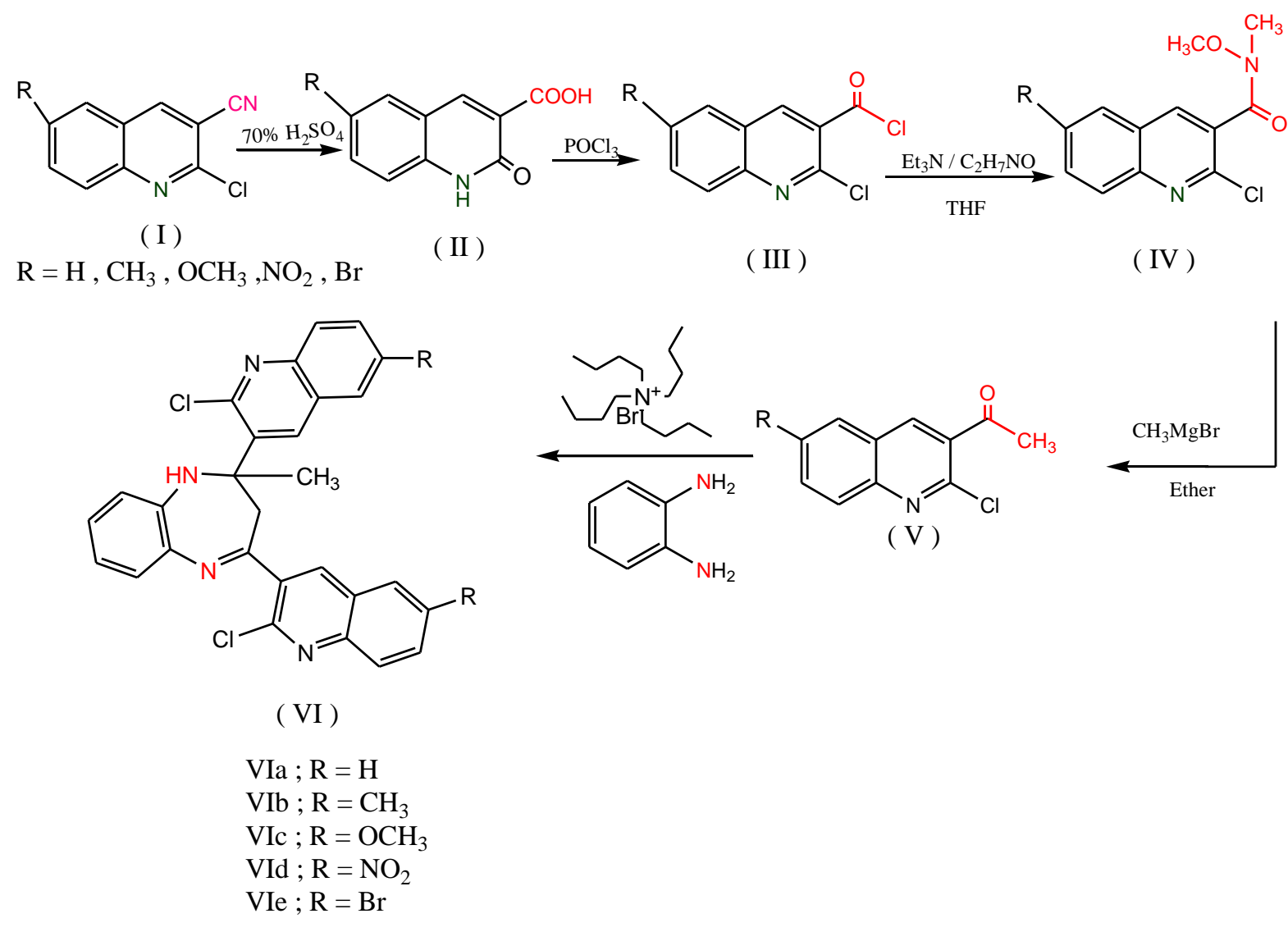

(Scheme1)

\section{EXPERIMENTAL}

\subsection{General}

Melting points were measured in capillary tube on a Graffin melting point apparatus and are uncorrected. The IR spectra were recorded on Pye Unicam SP 1000 IR spectrophotometer using $\mathrm{KBr}$ discs $\left(\lambda \max\right.$ in $\left.\mathrm{cm}^{-1}\right)$. ${ }^{1} \mathrm{HNMR}$ spectra were performed either on a Jeol ECA $(500 \mathrm{MHz})$ or Gemini $300 \mathrm{BB}(300 \mathrm{MHz})$ spectrometer, using TMS as internal standard and DMSO- $d 6$ as solvent; the chemical shifts are reported in ppm $(\delta)$ and coupling constant $(\mathrm{J})$ values are given in Hertz $(\mathrm{Hz})$. Signal multiplicities are represented by $\mathrm{s}$ (singlet), d (doublet), $\mathrm{t}$ (triplet), q (quadruplet), and m (multiplet). All of the new compounds were analyzed for $\mathrm{C}, \mathrm{H}$ and $\mathrm{N}$ and agreed with the proposed structures within $\pm 0.4 \%$ of the theoretical values by the automated CHN analyzer at the Regional Center for Mycology and Biotechnology (RCMB), Al-Azhar University, Cairo, Egypt. Mass spectra were recorded on Hewlett Packard 5988 spectrometer at the RCMB. The purity of the compounds was checked by thin layer chromatography (TLC) on Merck silica gel 60 F254 precoated sheets. The starting Compounds( I-III ) were prepared according to reported method (Wright, 1985; Neelima, et al., 1986; Cyrous, et al., 2006; Monir, et al., 2004; Hang and Browne, 2010).

\subsubsection{Chemistry}

The synthesis of the target compounds was achieved following the routes depicted in Scheme 1. Hydrolysis of (I) with $\mathrm{H}_{2} \mathrm{SO}_{4}(70 \%)$ in ethanol gave 6-substituted 2-oxo1,2dihydroquinoline-3-carboxylic acids (II) in good yields, which when heated in boiling phosphoryl chloride it gave 6-substituted 2-chloroquinoline-3-carbonyl chloride (III), which 
recrystallized from ethanol. Subsequently, (III) were reacted with $N, O$-dimethyl hydroxylamine in the presence of triethylamine $(1.58 \mathrm{~g})$ and THF, to give 2-chloro-Nmethoxy-N-methylquinoline-3-carboxamide derivatives (IV) that dried and crystallized from ethanol. This on further reaction with Grignard reagent (methyl magnesium bromide) in ammonium chloride and ether at room temperature gave 2-chloro-3-acetylquinoline derivatives $(\mathbf{V})$ the structure of compounds $(\mathbf{V})$ was confirmed on the basis of analytical and spectral data. The started compound (I-III) were synthesized according to reported procedures (Wright, 1985; Neelima, et al., Cyrous, et al., 2006; Monir, et al.,2004; Hang, et al., 2010).

General procedure for the synthesis of 6- substituted-2-Chloro- $N$-methoxy- $N$ methylquinoline-3-carboxamide (IVa-e)

To a solution of (III) in dry THF $(10 \mathrm{~mL})$, a solution of $N$, $O$-dimethyl hydroxylamine in THF (prepared from $2.2 \mathrm{mmol}$ of $\mathrm{N}, \mathrm{O}$-dimethyl hydroxylamine hydrochloride, and $2.2 \mathrm{mmol}$ of triethylamine in $5 \mathrm{~mL}$ of dry THF was added at $20{ }^{\circ} \mathrm{C}$ over $5 \mathrm{~min}$. The reaction mixture was stirred at r.t. for $24 \mathrm{~h}$. The solvent was removed in vacuo and the residue was dissolved in EtOAc. The organic layer was washed sequentially with saturated citric acid, satd. $\mathrm{Na}_{2} \mathrm{CO}_{3}, \mathrm{H}_{2} \mathrm{O}$, and dried over $\mathrm{MgSO}_{4}$. Evaporation in vacuo to dryness gave the desired products (IVa-e), which were recrystallized from the appropriate solvent.

\section{2-Chloro- $N$-methoxy- $N$-methylquinoline-3-carboxamide (IVa)}

Yield $70 \%$, m.p. 205-206 ${ }^{\circ} \mathrm{C}$. IR $(\mathrm{KBr}) \mathrm{cm}^{-1}, 2980$, 2830, 1640. Anal. Calc. For $\mathrm{C}_{12} \mathrm{H}_{11} \mathrm{ClN}_{2} \mathrm{O}_{2}$ : C, 57.49; H, 4.42; N, 11.17 . Found C, 57.12; H, 4.66; N, 11.09

\section{2-Chloro-6-methyl- $N$-methoxy- $N$-methylquinoline-3-carboxamide (IVb)}

Yield $80 \%$, m.p. $221-222{ }^{\circ} \mathrm{C}$. IR $\left(\mathrm{KBr}, \mathrm{cm}^{-1}\right): 2975,2825,1630,{ }^{1} \mathrm{HNMR}\left(\mathrm{CDCl}_{3}\right), \delta 2.30$ (s, 3H, N-Me); 2.52 (s, 3H, 6-Me); 3.1 (s, 3H, O-CH 3 ), 7.30 (s, 1H, $\mathrm{H}_{5}$-quinoline), 7.807.82 (d, $1 \mathrm{H}, \mathrm{H}_{7}$-quinoline), 7.95-7.98(d, 1H, $\mathrm{H}_{8}$-quinoline), 8.20 (s, $1 \mathrm{H}, \mathrm{H}_{4}$-quinoline), . Mass: $m / z 264.68(45.12, \mathrm{M}+), 249\left(35, \mathrm{M}-\mathrm{CH}_{3}\right), 234\left(100, \mathrm{M}-\mathrm{C}_{2} \mathrm{H}_{6}\right), 218\left(62.1 \mathrm{M}-\mathrm{C}_{2} \mathrm{H}_{6} \mathrm{O}\right)$ $176\left(52, \mathrm{M}-\mathrm{C}_{3} \mathrm{H}_{6} \mathrm{NO}_{2}\right), 161\left(23.9, \mathrm{M}-\mathrm{C}_{4} \mathrm{H}_{9} \mathrm{NO}_{2}\right)$. . Anal. Calc. For $\mathrm{C}_{13} \mathrm{H}_{13} \mathrm{ClN}_{2} \mathrm{O}_{2}$ : C, 58.99; H, 4.95; N, 10.58. Found C, 58.76; H, 4.51; N, 11.00

\section{2-Chloro-6-methoxy- $N$-methoxy- $N$-methylquinoline-3-carboxamide (IVc).}

Yield $65 \%$, m.p. $235-236{ }^{\circ} \mathrm{C}$. IR $\left(\mathrm{KBr}, \mathrm{cm}^{-1}\right): 2980,2830,1635 .{ }^{1} \mathrm{HNMR}\left(\mathrm{CDCl}_{3}\right) \delta 2.20$ (s, $3 \mathrm{H}$, , N-Me); 2.40 (s, 3H, 6-OMe); 3.22 (s, 3H, O-CH 3 ), 7.38 (s, 1H, H $\mathrm{H}_{5}$-quinoline), 7.887.90 (d, 1H, $\mathrm{H}_{7}$-quinoline), 8.14-8.16(d, 1H, $\mathrm{H}_{8}$-quinoline), 8.36 (s, $1 \mathrm{H}, \mathrm{H}_{4}$-quinoline), Mass: $m / z 280.71(40.3, \mathrm{M}+), 265\left(25, \mathrm{M}-\mathrm{CH}_{3}\right), 250\left(100, \mathrm{M}-\mathrm{C}_{2} \mathrm{H}_{6}\right), 234\left(55.80 \mathrm{M}-\mathrm{C}_{2} \mathrm{H}_{6} \mathrm{O}\right)$ 220(44.2,M- $\left.\mathrm{C}_{2} \mathrm{H}_{6} \mathrm{NO}\right), 192$ (25.9, $\left.\mathrm{M}-\mathrm{C}_{3} \mathrm{H}_{6} \mathrm{NO}_{2}\right), 161\left(15.2 \mathrm{M}-\mathrm{C}_{4} \mathrm{H}_{9} \mathrm{NO}_{3}\right)$. Anal. Calc. For $\mathrm{C}_{13} \mathrm{H}_{13} \mathrm{ClN}_{2} \mathrm{O}_{3}$ : C, 55.62; H, 4.67; N, 9.98. Found C, 55.35; H, 4.83; N, 10.12

\section{i2-Chloro-6-nitro- $N$-methoxy- $N$-methylquinoline-3-carboxamide (IVd).}

Yield $40 \%$, m.p. $259-260{ }^{\circ} \mathrm{C}$. IR (KBr, $\left.\mathrm{cm}^{-1}\right)$ : 2976, 2830, 1632. Mass: $m / z 295.68$ (33.50, $\mathrm{M}+)$. Anal. Calc. For $\mathrm{C}_{12} \mathrm{H}_{10} \mathrm{ClN}_{3} \mathrm{O}_{4}$ : C, 48.74; H, 3.41; N, 14.21. Found. C, 49.02; H, 3.26; $\mathrm{N}, 14.45$. 


\section{2-Chloro-6-bromo- $N$-methoxy- $N$-methylquinoline-3-carboxamide (IVe).}

Yield $55 \%$, m.p. $243-244{ }^{\circ} \mathrm{C}$. IR $\left(\mathrm{KBr}, \mathrm{cm}^{-1}\right): 2982,2835,1633 .{ }^{1} \mathrm{HNM} \mathrm{R}\left(\mathrm{CDCl}_{3}\right), \delta 2.35$ (s, 3H, N-Me); 2.60 (s, 3H, N- O- $\mathrm{CH}_{3}$ ), 7.25-7.27 (d, 1H, $\mathrm{H}_{8}$-quinoline), 8.60 (s, 1H, $\mathrm{H}_{4-}$ quinoline), 7.40-7.42 (d, $1 \mathrm{H}, \mathrm{H}_{7}$-quinoline), 7.55 (d, $1 \mathrm{H}, \mathrm{H}_{5}$-quinoline), Mass: $\mathrm{m} / z, 329.70$ (12., $\mathrm{M}+), 331.02(3.9 ., \mathrm{M}+2) 314\left(5, \mathrm{M}-\mathrm{CH}_{3}\right), 299\left(7, \mathrm{M}-\mathrm{C}_{2} \mathrm{H}_{6}\right), 283\left(16.81, \mathrm{M}-\mathrm{C}_{2} \mathrm{H}_{6} \mathrm{O}\right)$ 269(18, M- $\left.\mathrm{C}_{2} \mathrm{H}_{6} \mathrm{NO}\right), 190\left(23.9, \mathrm{M}-\mathrm{C}_{3} \mathrm{H}_{6} \mathrm{BrNO}_{2}\right)$. Anal. Calc. For $\mathrm{C}_{12} \mathrm{H}_{10} \mathrm{Br} \mathrm{ClN}_{2} \mathrm{O}_{2}$ : C, 43.73; H, 3.06; N, 8.50. Found C, 44.05; H, 3.32; N, 8.17

\section{General procedure for the synthesis of 1-(2-chloro-6-substituted-quinolin-3-yl)ethanone} (Va-e)

In a typical flask experiment's 0.02 mol of Grignard reagent was added at once to stirred solution of (IV) in $100 \mathrm{cc}$ of dry ether that previously cooled by ice / acetone mixture ,the added Grignard reagent were cooled also previously. After stirring for 2-3h the cool bath was removed and the mixture treated with ammonium chloride solution to get the crud product of compounds (Va-e) at room temperature.

\section{1-(2-chloroquinolin-3-yl)ethanone (Va)}

Yield $75 \%$, m.p. $173-174{ }^{\circ} \mathrm{C}$. IR (KBr, cm $\left.\left.{ }^{-1}\right): 2985,2834,1690 .{ }^{1} \mathrm{HNMR}_{(\mathrm{CDCl}}\right), \delta 1.90(\mathrm{~s}$, $\left.3 \mathrm{H}, \mathrm{CH}_{3}\right), 7.30-7.32$ (d, 1H, $\mathrm{H}_{5}$-quinoline), 7.40-7.42 (t, 1H, $\mathrm{H}_{6}$-quinoline), 7.65-7.68(t, $1 \mathrm{H}$, $\mathrm{H}_{7}$-quinoline), 7.90-7-92(t, $1 \mathrm{H}, \mathrm{H}_{8}$-quinoline), 8.36 (s, 1H, $\mathrm{H}_{4}$-quinoline),. Anal. Calc. For $\mathrm{C}_{11} \mathrm{H}_{8}$ CINO: C, 64.25; H, 3.92; N, 6.81. Found. C, 64.11; H, 4.18; N, 6.59

\section{1- (2-chloro-6-methylquinolin-3-yl)ethanone (Vb)}

Yield $85 \%$, m.p. $189-190{ }^{\circ} \mathrm{C} .{ }^{1} \mathrm{HNMR}\left(\mathrm{CDCl}_{3}\right), \delta 1.88\left(\mathrm{~s}, 3 \mathrm{H}, \mathrm{CH}_{3}\right), 2.55\left(\mathrm{~s}, 3 \mathrm{H}, \mathrm{CH}_{3^{-}}\right.$ quinoline), 7.32-7.34 (s, 1H, $\mathrm{H}_{5}$-quinoline), 7.70-7.72(d, 1H, $\mathrm{H}_{7}$-quinoline), 7.90-7-92(d, $1 \mathrm{H}, \mathrm{H}_{8}$-quinoline), 8.20 (s, $1 \mathrm{H}, \mathrm{H}_{4}$-quinoline), . Anal. Calc. For $\mathrm{C}_{12} \mathrm{H}_{10} \mathrm{ClNO}: \mathrm{C}, 65.61 ; \mathrm{H}$, 4.59; N, 6.38 .Found C, 65.55; H, 4.57; N, 6.70.

\section{1- (2-chloro-6-methoxyquinolin-3-yl)ethanone (Vc)}

Yield $72 \%$, m.p. $206-207{ }^{\circ} \mathrm{C} .{ }^{1} \mathrm{HNMR}\left(\mathrm{CDCl}_{3}\right), \delta 1.85\left(\mathrm{~s}, 3 \mathrm{H}, \mathrm{CH}_{3}\right), 2.59\left(\mathrm{~s}, 3 \mathrm{H}, \mathrm{OCH}_{3-}\right.$ quinoline), 7.37 (s, 1H, $\mathrm{H}_{5}$-quinoline), 7.71-7.73(d, 1H, $\mathrm{H}_{7}$-quinoline), 7.90-7-92(d, 1H, $\mathrm{H}_{8-}$ quinoline), 8.26 (s, $1 \mathrm{H}, \mathrm{H}_{4}$-quinoline),. Anal. Calc. For $\mathrm{C}_{12} \mathrm{H}_{10} \mathrm{ClNO}_{2}: \mathrm{C}, 61.16 ; \mathrm{H}, 4.28 ; \mathrm{N}$, 5.94 . Found $\mathrm{C}, 61.43 ; \mathrm{H}, 4.55 ; \mathrm{N}, 5.90$.

\section{1- (2-chloro-6-nitroquinolin-3-yl)ethanone (Vd)}

Yield $42 \%$, m.p. $214-215{ }^{\circ} \mathrm{C} .\left(\mathrm{KBr}, \mathrm{cm}^{-1}\right): 3090,2870,1695 .{ }^{1} \mathrm{HNMR}\left(\mathrm{CDCl}_{3}\right), \delta 1.85$ (s, $3 \mathrm{H}, \mathrm{CH}_{3}$ ), 7.60-7.62(d, 1H, $\mathrm{H}_{8}$-quinoline). 7.80-7.82 (d, 1H, $\mathrm{H}_{7}$-quinoline), 7.95 (s, $1 \mathrm{H}, \mathrm{H}_{5^{-}}$ quinoline), 8.35 (s, $1 \mathrm{H}, \mathrm{H}_{4}$-quinoline),. Anal. Calc. For $\mathrm{C}_{11} \mathrm{H}_{7} \mathrm{ClN}_{2} \mathrm{O}_{3}: \mathrm{C}, 52.71 ; \mathrm{H}, 2.82 ; \mathrm{N}$, 11.18. Found C, 53.07; H, 3.14; N, 11.02 .

\section{1- (2-chloro-6-bromoquinolin-3-yl)ethanone (Ve)}

Yield $49 \%$, m.p. $195-196{ }^{\circ} \mathrm{C}$. Mass: $m / z, 284.54(19, \mathrm{M}+)$. Anal. Calc. For $\mathrm{C}_{11} \mathrm{H}_{7} \mathrm{Br} \mathrm{ClNO}$ : C, 46.43; H, 2.48; N, 4.92. Found C, 46.19; H, 2.76; N, 4.98 . 
General procedure for the synthesis of substituted 2,4-bis(2-chloro-quinolin-3-yl) -2,3 dihydro-1H-benzo[b][ 1,5]- diazepine ( VIa-e)

A mixture of $o$-phenylenediamine $(10 \mathrm{mmole})$, and (Va-e) $(0.01 \mathrm{~mole})$ and phase transfer catalyst tetrabutylammonium bromide (catalytic amount) was heated under reflux for $50 \mathrm{~min}$ in ethyl alcohol $(10 \mathrm{~mL})$ at $60{ }^{\circ} \mathrm{C}$ with stirring ,after completion of reaction (monitored by TLC) the reaction mixture was cooled and poured on crushed ice, extracted from ethyl acetate $(30 \mathrm{~mL})$ and washed with water and brine $(20 \mathrm{~mL}$ each). The solvent was removed by distillation under reduced pressure. The crude product was purified by column chromatography (eluent, ethyl acetate - pet-ether).The corresponding new 1, 5 benzodiazepines derivatives were obtained in $80-95 \%$ yield.

\section{2,4-bis(2-chloroquinolin-3-yl) -2-methyl -2,3 -dihydro- $1 H$-benzo[b][ 1,5$]$ - diazepine ( VIa)}

Yield $85 \%$, m.p. $142-143{ }^{\circ} \mathrm{C} .\left(\mathrm{KBr}, \mathrm{cm}^{-1}\right)$ : 3335, 3105, 2959, 2861. Anal. Calc. For $\mathrm{C}_{28} \mathrm{H}_{20}$ $\mathrm{Cl}_{2} \mathrm{~N}_{4}$ : C, 69.57; H, 4.17; N, 11.59. Found. C, 69.20; H, 4.36; N, 11.63 .

\section{2,4-bis(2-chloro-6-methylquinolin-3-yl) $\quad$-2-methyl $\quad-2,3 \quad$-dihydro-1H-benzo[b][ $\quad 1,5]-$ diazepine ( VIb)}

Yield $95 \%$, m.p. $138-139{ }^{\circ} \mathrm{C} .\left(\mathrm{KBr}, \mathrm{cm}^{-1}\right)$ : 3330, 3097, 2843. ${ }^{1} \mathrm{HNMR}$ (DMSO, $\left.\mathrm{D}_{2} \mathrm{O}\right), \delta$ : 1.1(s,3H, $\mathrm{CH}_{3}$ at $\left.\mathrm{C} 2\right), 1.84$ (s, $2 \mathrm{H}-\mathrm{H}_{3}$-diazepine), 2.39(s, 6H-2( $\left.\left.\mathrm{CH}_{3}\right)\right), 4.17(\mathrm{~s}, 1 \mathrm{H}, \mathrm{NH}$ of BDP that exchangeable with $\left.\mathrm{D}_{2} \mathrm{O}\right) .6 .17-6.20\left(\mathrm{t}, 2 \mathrm{H},-\mathrm{H}_{4}, \mathrm{H}_{5}\right.$ of phenyl), 6.25-6.27( $\mathrm{d}, 2 \mathrm{H},-\mathrm{H}_{3}$, $\mathrm{H}_{6}$ of phenyl), 7.13(s, 2H, $\mathrm{H}_{5}$ of quinoline), 7.20-7.24(d, $2 \mathrm{H}, \mathrm{H}_{7}$-quinolin), 7.26-7.28(d, $2 \mathrm{H}$, $\mathrm{H}_{8}$ of quinoline), 8.12(s, $2 \mathrm{H}-\mathrm{H}_{4}$ of quinoline), Anal. Calc. For $\mathrm{C}_{30} \mathrm{H}_{24} \mathrm{Cl}_{2} \mathrm{~N}_{4}: \mathrm{C}, 70.45 ; \mathrm{H}$, $4.73 ; \mathrm{N}, 11.95$. Found, C, 70.80; H, 4.50; N, 11.59 .

\section{2,4-bis(2-chloro-6-methoxyquinolin-3-yl) $\quad$-2-methyl $\quad-2,3 \quad$-dihydro-1H-benzo[b][ 1,5$]-$ diazepine ( VIc)}

Yield $92 \%$, m.p. $121-122{ }^{\circ} \mathrm{C}$. IR (KBr, cm $\left.{ }^{-1}\right): 3340,3118,2830 .{ }^{1} \mathrm{HNMR}$ (DMSO, $\left.\mathrm{D}_{2} \mathrm{O}\right), \delta$ : $1.2\left(\mathrm{~s}, 3 \mathrm{H}, \mathrm{CH}_{3}\right), 1.88\left(\mathrm{~s}, 2 \mathrm{H}-\mathrm{H}_{3}\right.$-diazepine), 3.39(s, 6H-2(O- $\left.\left.\mathrm{CH}_{3}\right)\right), 4.25(\mathrm{~s}, 1 \mathrm{H}, \mathrm{NH}$ of BDP that exchangeable with $\left.\mathrm{D}_{2} \mathrm{O}\right) 6.21-6.25\left(\mathrm{t}, 2 \mathrm{H},-\mathrm{H}_{4}, \mathrm{H}_{5}\right.$ of phenyl), 6.29-6.32(d, $2 \mathrm{H},-\mathrm{H}_{3}, \mathrm{H}_{6}$ of phenyl), 6.9(s, 2H, $\mathrm{H}_{5}$ of quinoline), 7.32-7.34(d, $2 \mathrm{H}, \mathrm{H}_{7}$-quinolin)7.46-7.48(d, $2 \mathrm{H}, \mathrm{H}_{8}$ of quinoline), $8.02\left(\mathrm{~s}, 2 \mathrm{H}-\mathrm{H}_{4}\right.$ of quinoline) . Mass: $\mathrm{m} / \mathrm{z} 543.44\left(15.6, \mathrm{M}^{+}\right)$.Anal. Calc. For $\mathrm{C}_{30} \mathrm{H}_{24} \mathrm{Cl}_{2} \mathrm{~N}_{4} \mathrm{O}_{2}$ : C, 66.30; H, 4.45; N, 10.31. Found. C, 66.03; H, 4.48; N, 10.15 .

\section{2,4-bis(2-chloro-6-nitroquinolin-3-yl) $\quad$-2-methyl $\quad-2,3 \quad$-dihydro-1H-benzo[b][ 1,5$]-$ diazepine ( VId)}

Yield $92 \%$, m.p. $150-152{ }^{\circ} \mathrm{C}$. IR $\left(\mathrm{KBr}, \mathrm{cm}^{-1}\right): 3395,3125,2842 .{ }^{1} \mathrm{HNMR}\left(\mathrm{DMSO}, \mathrm{D}_{2} \mathrm{O}\right), \delta$ : $1.11\left(\mathrm{~s}, 3 \mathrm{H}, \mathrm{CH}_{3}\right.$ at $\mathrm{C} 2$-diazepine), $1.88\left(\mathrm{~s}, 2 \mathrm{H}-\mathrm{H}_{3}\right.$-diazepine), $4.19(\mathrm{~s}, 1 \mathrm{H}, \mathrm{NH}$, that exchangeable with $\left.\mathrm{D}_{2} \mathrm{O}\right)$ 6.21-6.23(t, $2 \mathrm{H}, \mathrm{H}_{4}, \mathrm{H}_{5}$ of phenyl), 6.33-6.35(d, 2H , $\mathrm{H}_{3}, \mathrm{H}_{6}$ of phenyl), 7.37-7.39(d, $2 \mathrm{H}, \mathrm{H}_{8}$-quinolin), $8.10\left(\mathrm{~s}, 2 \mathrm{H}, \mathrm{H}_{4}\right.$ of quinoline), 8.48-8.50(d, $2 \mathrm{H}, \mathrm{H}_{7}$ of quinoline), $8.63\left(\mathrm{~s}, 2 \mathrm{H}, \mathrm{H}_{5}\right.$ of quinoline) . Mass: $\mathrm{m} / \mathrm{z} 573.39\left(11.5, \mathrm{M}^{+}\right)$, Anal. Calc. For $\mathrm{C}_{28} \mathrm{H}_{18} \mathrm{Cl}_{2} \mathrm{~N}_{6} \mathrm{O}_{4}$ : C, 58.65; H, 3.16; N, 14.66. Found, C, 58.77; H, 3.47; N, 14.91 . 


\section{2,4-bis(2-chloro-6-bromoquinolin-3-yl) $\quad$-2-methyl $\quad-2,3 \quad$-dihydro-1H-benzo[b][ 1,5$]-$ diazepine ( VIe)}

Yield $92 \%$, m.p. $150-152{ }^{\circ} \mathrm{C}$. IR $\left(\mathrm{KBr}, \mathrm{cm}^{-1}\right): 3435,3092,2810$, . Mass: m/z 641.18 (9.14, $\left.\mathrm{M}^{+}\right), 643\left(4.5, \mathrm{M}^{+2}\right)$. Anal. Calc. For $\mathrm{C}_{28} \mathrm{H}_{18} \mathrm{Br}_{2} \mathrm{Cl}_{2} \mathrm{~N}_{4}$ : C, 52.45; H, 2.83; N, 8.74. Found, C, $52.23 ; \mathrm{H}, 2.65 ; \mathrm{N}, 8.80$.

\section{RESULT AND DISCUSSION}

Tetrabutylammonium bromide is a cheap and readily available reagent it efficiently catalyze the condensation of ketones with $o$-phenelendiamine at $60{ }^{\circ} \mathrm{C}$ under mild conditions in short reaction time $(50 \mathrm{~min})$ with excellent yield of the product. In our work a series of [1,5]- Benzodiazepine derivatives were prepared from starting intermediate 2-oxo-1,2dihydroquinoline-3-carboxylic acid derivatives which prepared according to the reported procedure ${ }^{14-18}$. The structures of compound (II) were confirmed by ${ }^{1} \mathrm{HNMR},{ }^{13} \mathrm{C}-\mathrm{NMR}$, In the ${ }^{1} \mathrm{H}-\mathrm{NMR}$ spectra, where two sharp proton signal observed at the $\delta 5.4$ and $11.68 \mathrm{ppm}$, one belong $\mathrm{OH}$ at $\mathrm{C}-2$ and one belong $\mathrm{COOH}$ respectively, and due to resonance isomerism the $\mathrm{NH}$ (secondry amine) it appear at higher chemical shift at 8.9 as abroad signal more than expected due to neighboring carbonyl group, In the ${ }^{13} \mathrm{C}-\mathrm{NMR}$ spectra of these compounds one $\mathrm{C}=\mathrm{O}$ peak at about $178 \mathrm{ppm}$ and one around $166 \mathrm{ppm}$ corresponded to the signals of the 3 -carboxylic acid and carbonyl groups in the quinoline rings. On contrary the IR spectra of compound (III) showed the disappearance of $\mathrm{OH}$ streatching band and this explaine the conversion of acid into acid chloride and the mass spectra of compound (III) confirm the conversion of carbonyl at C-2 into chloride moiety, so when the compound (III) react $\mathrm{N}, \mathrm{O}$ dimethyl hydroxylamine it produce the compound (IV) which IR spectra confirm the presence of these compound because it showed clearly decreasing of stretching absorption band of $\mathrm{C}=\mathrm{O}$ from $1812 \mathrm{~cm}^{-1}$ and appearance of sharp medium stretching absorption bands at range of $1636 \mathrm{~cm}^{-1}$ which belong to $(\mathrm{C}=\mathrm{O})$ for amide, when compound (IV) react with alkyl Grignard reagent it produce compound (V), which upon cyclocondensation with $O$ phenelendiamine it afford new 1,5-benzodiazepine derivatives (VI), where the elemental analysis and spectral data confirm the existence of this cyclocondensation in which the ${ }^{1} \mathrm{HNMR}$ of new 1,5-benzodiazepines contain singlet signal due to $\mathrm{CH}_{3}$ at $\mathrm{C}$-2, in addition the presence of $\mathrm{NH}$ singlet signal at 4.17-4.25, furthermore the presence of singlet signal due to the two hydrogen at C-3 of benzodiazepine ring and all this fact will prove this cyclocondensation reaction and formation of 1,5-benzodiazepine ring .

\section{Antimicrobial activity:}

The newly synthesized of [1,5]-benzodiazepine compounds were screened for their in-vitro antibacterial activity against Staphylococcus aureus, Bacillus subtilius , Pseudomonas aeruginosa , Escherichia coli and candida albicans bacterial stains by serial plate dilution method (Barry, 1991), Serial dilutions of the drug in Muller Hinton broth were taken in tubes and their $\mathrm{pH}$ was adjusted to 5.0 using phosphate buffer. A standardized suspension of the test bacterium was inocubated for 16 to 18 hours at $37^{\circ} \mathrm{C}$. The minimum inhibitory concentration (MIC) was noted by observing the lowest concentration of the drug at which there was no visible growth. Numbers of antibacterial discs were placed on the agar for the sole purpose of producing zones of inhibition in the bacterial lawn. Twenty milliliters of agar media was poured into each petri dish. Excess of suspension was decanted and plates were dried by placing in an incubator at $37{ }^{\circ} \mathrm{C}$ for an hour. Using a punch, wells were made on these seeds agar plates and minimum inhibitory concentrations of the test compounds in 
dimethyl sulfoxide were added into each labeled well. A control was also prepared for the plates in the same way using DMSO as a solvent. The petri dishes were prepared in triplicate and maintained at $370 \mathrm{C}$ for 3 to 4 days. Antibacterial activity was determined by measuring the diameter of inhibition zone. Activity of each compound was compared with ampicillin and Nystatin as standard. All the synthesized compounds were taken at different concentration of 500 and $600 \mu \mathrm{g} / \mathrm{ml}$.The result was compared with the ampicillin (500 $\mu \mathrm{g} / \mathrm{ml})$ and Nystatin $(500 \mu \mathrm{g} / \mathrm{ml})$ as in the (Table 1).

Table 1: Antimicrobial activity of synthesized 1,5-Benzodiazepines (VIa - e)

\begin{tabular}{|c|c|c|c|c|c|c|}
\hline \multirow{2}{*}{$\begin{array}{c}\text { COMP. } \\
\text { NO. }\end{array}$} & $\begin{array}{c}\text { CONCENT } \\
\text {-RATION } \\
(\text { MG/ML) }\end{array}$ & $\begin{array}{c}\text { MICROOPhlococcus } \\
\text { aureus }\end{array}$ & $\begin{array}{c}\text { Basillus } \\
\text { subtilis }\end{array}$ & $\begin{array}{c}\text { Escherichia } \\
\text { coli }\end{array}$ & $\begin{array}{c}\text { Pseudomonas } \\
\text { aeruginosa }\end{array}$ & $\begin{array}{c}\text { Candida } \\
\text { albicans }\end{array}$ \\
\hline \multirow{2}{*}{ VIa } & 500 & 16.2 & 18.2 & 16.3 & 15.2 & 15.3 \\
\cline { 2 - 7 } & 600 & 17.6 & 19.5 & 17.3 & 16.5 & 15.4 \\
\hline \multirow{2}{*}{ VIb } & 500 & 17.1 & 15.8 & 16.3 & 15.3 & - \\
\cline { 2 - 7 } & 600 & 17.9 & 16.3 & 16.9 & 16.2 & - \\
\hline \multirow{2}{*}{ Vic } & 500 & 15.4 & 17.3 & 17.3 & 17.4 & 14.1 \\
\cline { 2 - 7 } & 600 & 16.8 & 18.9 & 18.8 & 18.3 & 15.5 \\
\hline \multirow{2}{*}{ Vid } & 500 & 18.3 & 15.7 & 16.6 & 16.6 & 15.7 \\
\cline { 2 - 7 } & 600 & 20.1 & 16.7 & 17.8 & 16.9 & 16.8 \\
\hline \multirow{2}{*}{ Vie } & 500 & 19.7 & 16.6 & 16.5 & 16.5 & 16 \\
\cline { 2 - 7 } & 600 & 21.3 & 17.3 & 17.7 & 17.1 & 17.3 \\
\hline Ampicillin & 500 & 22.0 & 20.3 & 23.0 & 19.1 & - \\
\hline Nystatine & 500 & - & - & - & - & 18.5 \\
\hline
\end{tabular}

From screening results of the final compounds, It showed moderate antimicrobial activity. The discussion and comparison of antibacterial activity were given with respect to ampicillin antibiotic and antifungal screening were compared with Nystatin.Microbiological testing of the newly synthesized compounds were performing in the regional center for Mycology and Biotechnology, Department of microbiology , Faculty of science , Al-Azher university , Cairo , Egypt .

\section{REFERENCE}

An, L.-T.; Ding, F.-Q.; Zou, J.-P.; Lu, X.-H. (2008): Montmorillonite K10: An efficient catalyst for solvent-free synthesis of 1,5-benzodiazepine derivatives. Synth. Commun; 38, 1259-1267.

Barry AL. (1991): Procedure for testing antimicrobial agents in agar media. In: V.L. Corian (Ed.). Antibiotics in Laboratory Medicine.Williams and Wilkins, Baltimore, MD, 1.

Chen, W.-Y.; Lu, J. (2005): Molecular iodine catalyzed one-pot synthesis of 1,5benzodiazepine derivatives under solvent-free conditions. Synlett, 1337-1339.

Cyrous $\boldsymbol{O}$.Kangani, David E .Kelly,Billy Day W., (2006): Tetrahedron letters , vol.47,35, 6289-92

Di Braccio M, Grossi G C, Roma G, Vargiu L, Mura M and Marongiu M, (2001): Eur J Med Chem., 36, 935-949.

Hang,B.L.Feringa, W.Browne., (2010): Org. Biomol. Chem, 8,4444. 
Heravi, M.M.; Sadjadi, S.; Oskooie, H.A. (2008): An Efficient Synthesis of 3H-1,5benzodiazepine Derivatives Catalyzed by Heteropolyacids as a Heterogeneous Recyclable Catalyst. J. Chin.Chem. Soc., 55, 842-845.

Herbert, J.A.L.; Suschitzky, H. (1974): Syntheses of heterocyclic compounds. Part XXIX. Substituted 2,3-dihydro-1H-1,5-benzodiazepines. J. Chem. Soc., Perkin Trans., $1,2657-2661$.

Kamal A, Shankaraiah N, Prabhakar S, Reddy C R, Markandeya N, Laxma $K$ and Devaiah X, (2008): Bioorg Med Chem Lett., 18, 2434-2439.

Kavali J. R and Badami B V, (2000): II Farmaco, 55(5), 406-409.

Kumar R and Joshi Y C, (2007): ARKIVOC, 13, 142-149.

Kumar, R.; Chaudhary, P.; Nimesh, S.; Verma, A. K.; Chandra, R. (2006): An efficient synthesis of 1,5-benzadiazepine derivatives catalyzed by silver nitrate. Green Chem., 8, 519-521.

Li, Z.; Sun, Y.; Ren, X.; Li, W.; Shi, Y.; Ouyang, P. (2007): Efficient synthesis of 1,5benzodiazepines mediated by sulfamic acid under neat condition or in solution. Synth. Commun., 37, 1609-1615.

Mohamed A Baseer, Asgar J Khan (2012): E-journal of chemistry, 9 (1) 407-4014

Monir A.S; Mohamad M Ismail; Saber E. S. Barakat; Ashraf A. A. Abdul-Rahman; Ashraf .H. Bayomi; Kamal M. A. El-gaml, (2004): synthesis and antimicrobial activity of some new 1H-pyrazolo[3,4-b]Qinoline derivatives, Bull.Pharm.Sci.-Assiut. Univ, vol. 27, part 2, 237-245

Neelima ,B. Bhat, Amiya. P. Bhaduri. J.Het. (1986): Chem.,23,295,,925-930.

Randall L. O, (1974): Psychopharmacological Agents, Ed., Gordon M, New York, Academic Press, 3, 175-281.

Roma G, Grossi G C, Di Braccio M, Ghia M andMattioli F, (1991):Eur J Med Chem., 26, 489.

Wright T.L., (1985): U.S.Pat.4,540,786

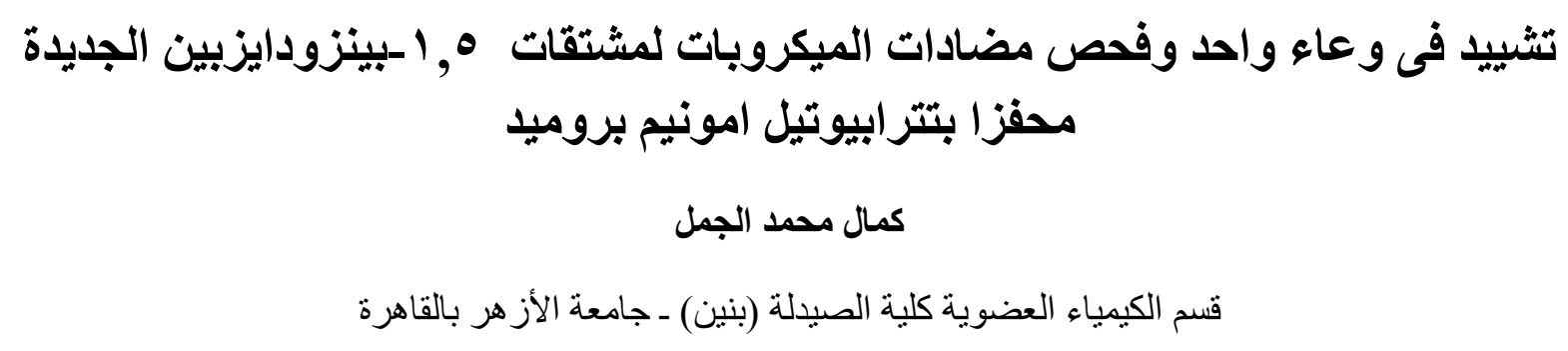

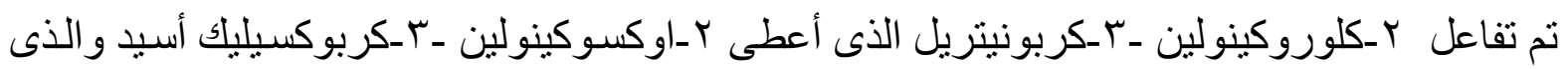

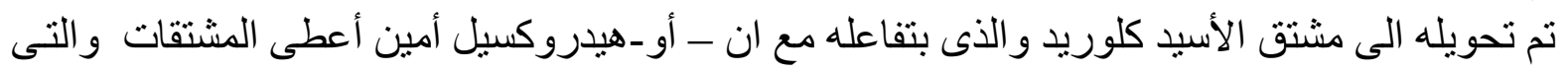

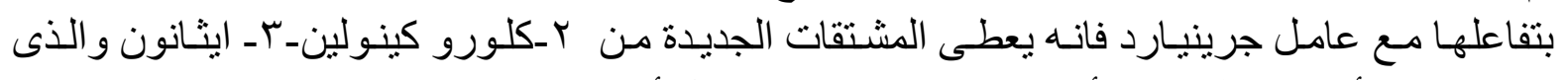

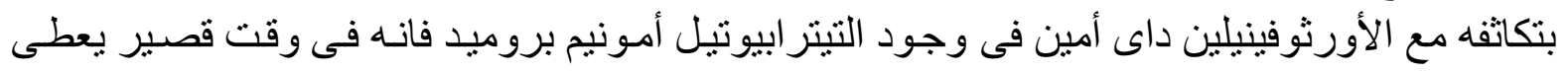

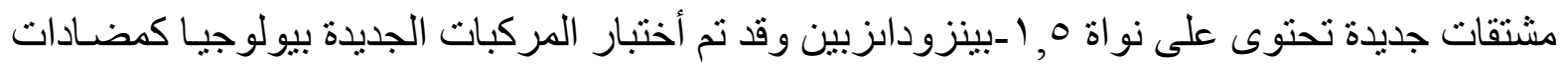
للبكتريا و الفطريات حيث أظهرت بعض المركبات فوه فاعلية مضادة لهذه الميكروبات 